\title{
Bacteria intestinal del mosquito puede frenar el desarrollo del parásito de la malaria*
}

A ntes de que el Plasmodium falciparum, el principal parásito causante de la malaria humana, pueda infectar a las personas, debe infectar a un mosquito que le sirve de huésped. Sin embargo, según un equipo de investigadores de la Escuela Bloomberg de Salud Pública de la Universidad Johns Hopkins y el Instituto de Investigación de la Malaria en Macha, Zambia, esto no siempre le resulta fácil. Dicho equipo informa que una bacteria que se encuentra de manera natural en los mosquitos produce una molécula de corta vida que puede matar al parásito P. falciparum en las primeras etapas

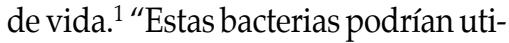
lizarse para desarrollar una estrategia de biocontrol" a fin de combatir la malaria, dice el autor principal George Dimopoulos, profesor adjunto del Departamento de Microbiología Molecular e Inmunología de la Universidad Johns Hopkins.

Dimopoulos y sus colegas aislaron bacterias del intestino medio de mosquitos Anopheles arabiensis recolectados en Zambia. Posteriormente, alimentaron a especímenes de los principales mosquitos transmisores de la malaria en África (An. gambiae) y Asia (An. stephensi) con estas bacterias. Observaron que ciertas bacterias gram-negativas inhibían el desarrollo temprano del $P$. falciparum en estos mosquitos. Un miembro recién descubierto del género Enterobacter, Esp_Z, inhibió casi por completo el desarrollo in vitro de los oocinetos, ooquistes y esporozoítos del $P$. falciparum.

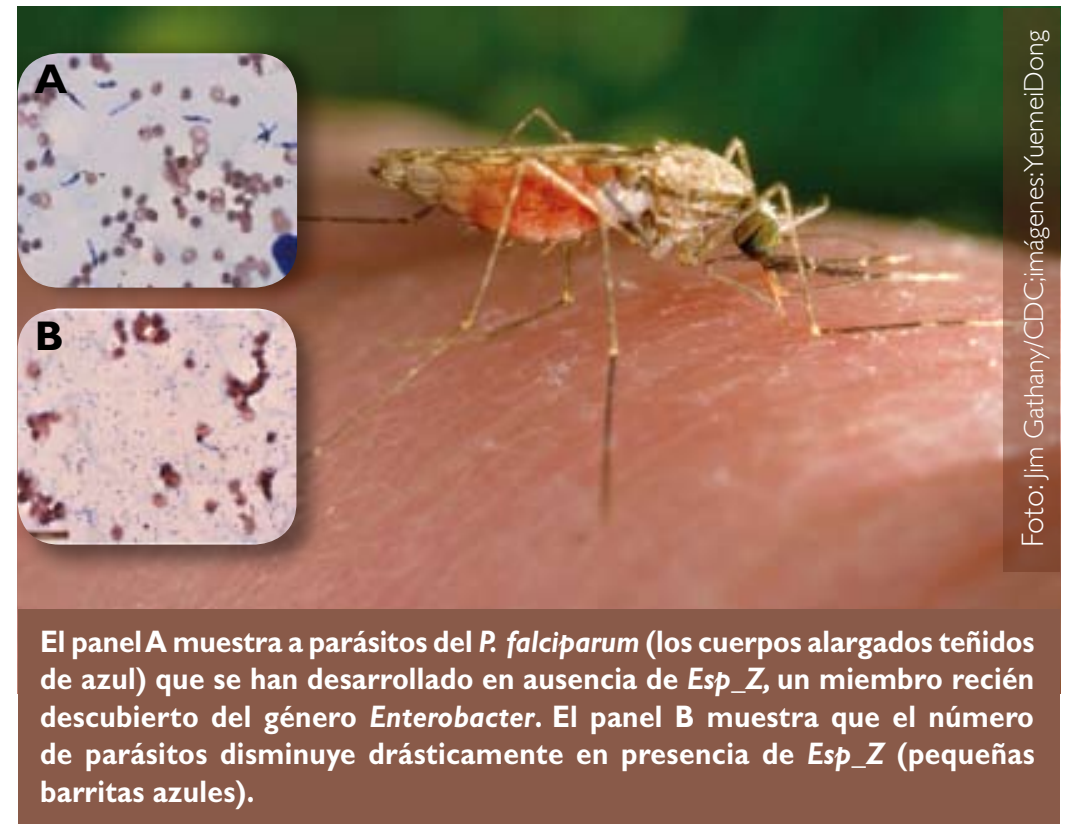

Otro estudio indicó que la eficacia de la bacteria era resultado de su producción de especies reactivas de oxígeno de las cuales se sabía ya que matan el $P$. falciparum. El estudio fue financiado en parte por el Instituto Nacional de Alergias y Enfermedades Infecciosas.

John Beier, un profesor de epidemiología y salud pública de la Universidad de Miami que no participó en la investigación considera que este hallazgo es "un descubrimiento significativo". Beier opina que el hecho de poder suministrar esta bacteria a los mosquitos puede reducir el índice de transmisión de malaria a los seres humanos. Las estrategias actuales para combatir la malaria, entre las que se incluye el uso de mosquiteros tratados con insecticida, el rociado de insecticidas en los interiores y los esfuerzos por eliminar los criaderos de los mosquitos, como el agua estancada, son insuficientes, señala Beier, para erradicar la enfermedad. Según las cifras más recientes de que se dispone, la Organización Mundial de la Salud reportó 247 millones de casos de malaria en 2008 y casi 1 millón de muertes, principalmente de niños en África. ${ }^{2}$

Dimopoulos señala que un método potencial de utilización de estas bacterias para combatir la malaria sería capitalizar el hambre de azúcar de los mosquitos. Mientras que las hembras requieren de la sangre únicamente para el desarrollo de 
los huevos, tanto las hembras como los machos necesitan alimentarse diariamente de azúcar; su alimento preferido es el néctar de las plantas. "Podríamos mezclar las bacterias con un néctar artificial y rociarlo sobre la vegetación", dice Dimopoulos, "o bien, podríamos desarrollar "estaciones de alimentación" para atraer a los mosquitos, para que se alimenten allí de néctar y al mismo tiempo recojan las bacterias".

Se están probando técnicas similares en otros países. En Mali, los investigadores reportaron que la aspersión de un cebo de jugo de fruta fermentado y mezclado con ácido bórico sobre las plantas redujo la población del An. gambiae en $90 \%$ en uno de los sitios del estudio. ${ }^{3}$ Por otra parte, un estudio realizado en Israel demostró que cuando se roció el agua azucarada fortalecida con el insecticida spinosad sobre los árboles frutales de los que los mosquitos solían alimentarse, prácticamente se erradicó la población de éstos. ${ }^{4,5}$

Beier señala que se requiere de más investigación para comprender el comportamiento alimentario, a base de azúcar, de los mosquitos en su estado natural, fenómeno que él mismo está estudiando. Añade que debe realizarse un esfuerzo para encontrar otras bacterias inhibidoras como las que fueron identificadas por Dimopoulos. "Me parece que es necesario demostrar cómo funcionarían estas bacterias en múltiples especies de mosquitos. Dondequiera que hay transmisión de la malaria, están presentes varias especies distintas de vectores competentes", dice.

Dimopoulos y sus colegas reportaron haber encontrado el Esp_Z únicamente en $25 \%$ de los mosquitos de la muestra. Afirma que esto puede ser un reflejo de lo caprichoso del muestreo, o que quizá no todos los mosquitos están expuestos a la bacteria, o bien, que la bacteria puede tener dificultad para colonizar el intestino del mosquito. Él y sus colegas están trabajando para ayudar a la bacteria a establecerse mejor en el interior de éste. "Por medio de múltiples rondas de selección es posible adaptar la bacteria para que logre una mejor colonización del mosquito", señala Dimopoulos.
Harvey Black, de Madison, WI, ha escrito para EHP desde 1994. Ha publicado asimismo en las revistas Environmental Science \& Technology, ChemMatters y Milwaukee Journal Sentinel.

\section{Referencias y notas}

I. Cirimotich CM, et al. Natural microbemediated refractoriness to Plasmodium infection in Anopheles gambiae. Science 332(6031):855-858 (20II); http://dx.doi.org//0.1 I26/ science. 1201618. 2. OMS.World Health Organization Media Centre Malaria Fact Sheet. Ginebra, Suiza: Organización Mundial de la Salud (abril de 2010). Disponible en: http://tinyurl.com/yolhob [consulta realizada el 27 de junio de $201 \mathrm{I}$ ].

3. Muller GC, et al. Successful field trial of attractive toxic sugar bait (ATSB) plant-spraying methods against malaria vectors in the Anopheles gambiae complex in Mali,West Africa. Malaria J 9:210 (2010); http://dx.doi.org//0.1 186/14752875-9-210.

4. Muller G, Schlein Y. Sugar questing mosquitoes in arid areas gather on scarce blossoms that can be used for control. Int J Parasitol 36(I0-II): I077-II 80 (2006); http://dx.doi. org//0.1016/j.jpara.2006.06.008.

5. Los autores observaron que al parecer otros insectos examinados en el estudio ingirieron spinosad, pero no hicieron ningún comentario sobre el modo en que se vieron afectados estos insectos.

\section{La calidad del aire en los espacios interiores}

\section{El impacto del cambio climático en el medio ambiente de los espacios interiores*}

$\mathrm{D}$ urante muchos años los investigadores han estado conscientes de los vínculos potenciales entre el cambio climático y la calidad del aire en los espacios exteriores. ${ }^{1}$ Son muchos menos los estudios que se han enfocado en el impacto del cambio climático en la calidad del aire en los espacios interiores. Sin embargo, un informe reciente del Instituto de Medicina (en inglés, IOM) concluye que la relación entre ambos amerita más atención y más acciones. ${ }^{2}$
"No hay muchas investigaciones sobre este tema, y se requiere de evidencias contundentes", dice John Spengler, científico ambiental de la Escuela de Salud Pública de Harvard, quien presidió el comité encargado de redactar el informe. “Este informe 